BMJ Open

Ophthalmology

\section{The prevalence of visual symptoms in poppers users: a global survey}

To cite: Davies AJ, Borschmann R, Kelly SP, et al. The prevalence of visual symptoms in poppers users: a global survey. BMJ Open Ophth 2016;1:1-6. doi:10.1136/bmjophth-2016000015

- Prepublication history and additional material is available. To view please visit the journal (http://dx.doi.org/ 10.1136/bmjophth-2016000015)

Received 29 June 2016 Revised 29 November 2016 Accepted 11 December 2016

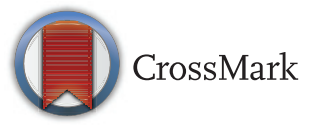

\section{${ }^{1}$ Department of}

Ophthalmology, Manchester Royal Eye Hospital, Manchester, UK

${ }^{2}$ Melbourne School of Population and Global Health, The University of Melbourne, Melbourne, Australia

${ }^{3}$ Murdoch Children's Research Institute, Royal Children's Hospital, Melbourne, Australia ${ }^{4}$ Department of Ophthalmology, Royal Bolton Hospital, Bolton, UK

${ }^{5}$ St. George's University of London, London, UK

${ }^{6}$ Institute for Social Science Research, University of Queensland, Brisbane,

Australia

${ }^{7}$ Department of Addictions, South London and Maudsley NHS Foundation Trust, London, UK

Correspondence to Dr Rohan Borschmann; rohan.borschmann@mcri. edu.au

\section{ABSTRACT}

Introduction and aims: The use of 'poppers' (volatile alkyl nitrites) has been associated with the development of visual symptoms secondary to the development of maculopathy. There are currently no data regarding the prevalence of this condition among poppers users. The aim of this study was to quantify the presence of visual symptoms among poppers users from a global cohort

Design and methods: The Global Drug Survey (GDS) conducts annual anonymous online surveys of drug and alcohol use. Within the 2012 GDS, questions were inserted regarding the presence of visual symptoms in poppers users.

Results: The GDS received a total of 21575 valid responses, with a total of 17479 from the UK, Australia, USA and Eurozone. Within these areas, 5152 (29.5\%) had used poppers within their lifetime and $1322(7.6 \%)$ within the previous year. Of the 'last year' users, when asked the question: 'Do you think poppers use has affected your eyesight?', 29 (2.2\%) people responded 'yes', $130(10.0 \%)$ responded 'maybe' and $1146(87.8 \%)$ responded 'no (17 people did not answer). Both multiple choice and free-text responses regarding the nature of visual symptoms correlated with the central visual disturbance that would be expected from maculopathy. There was significant increased symptom prevalence with age (likelihood ratio $\left(\chi^{2}\right)=19.0 ; p<0.001$ ).

Discussion and conclusions: This study demonstrates that a small, yet significant from a public health perspective, proportion of poppers users have visual symptoms. Clinical correlation is required to determine whether these reported symptoms are due to poppers associated maculopathy, or an alternative cause.

\section{INTRODUCTION}

'Poppers' are substances of abuse belonging to the volatile alkyl nitrite family of compounds. Inhalation of the fumes provides a brief sense of euphoria or arousal. ${ }^{1}$ They have been in common use for several decades and are a global phenomenon, with reports from many western countries including those in Europe, North America and Australasia ${ }^{1} 2$ documenting their high incidence of abuse. The particular alkyl nitrite compound has

\begin{abstract}
Key messages
What is already known about this subject?

Specific macular features associated with poppers abuse have been reported and are increasingly recognised by retinal specialists on clinical imaging.

What are the new findings?

This global study provides descriptive data on the visual symptoms that poppers users may experience. We also provide a review of all published cases of poppers maculopathy to date.

How might these results change the focus of research or clinical practice?

- The data provided will facilitate recognition of this disorder by the wider clinical community and will influence future clinical studies. Importantly, these results are of considerable ocular public health relevance and may assist legislators regarding the manufacture and sale of volatile nitrite products.
\end{abstract}

changed in recent years in response to European legislation. In the UK, it is reported that up to $10 \%$ of the general population have tried poppers, with $1 \%$ having done so within the past year. ${ }^{3}$ This rate is higher in the 'clubbing' (electronic dance music) and gay communities. ${ }^{4}{ }^{5}$ In many western countries poppers are illegal to sell for human consumption, yet not illegal to possess. They are therefore often sold for alternative uses such as video head cleaner or room deodorants and are typically easy to purchase on the high street or online.

Poppers have previously been described as low risk both physically and psychologically. ${ }^{6}$ However, since 2010 there have been numerous case reports and case series from Europe and Australia of poppers users who developed visual symptoms secondary to macular pathology; a condition referred to as 'poppers maculopathy'. ${ }^{7-21}$ More than 50 cases have been described (see table 1), all of which share similar symptoms including 
Table 1 Previously published cases of clinically confirmed poppers maculopathy

\begin{tabular}{|c|c|c|c|c|c|c|}
\hline Author/year & Type of series & Country & Cases (n) & Level of use & $\begin{array}{l}\text { Visual } \\
\text { impairment } \\
\text { (Snellen } \\
\text { acuity) }\end{array}$ & $\begin{array}{l}\text { Findings and other features of } \\
\text { note }\end{array}$ \\
\hline $\begin{array}{l}\text { Vignal- } \\
\text { clermont } \\
\text { et al/2010 }\end{array}$ & Case series & France & 4 & Varied & $\begin{array}{l}\text { Range 6/12- } \\
6 / 15\end{array}$ & Nil \\
\hline $\begin{array}{l}\text { Audo et al/ } \\
2011^{8}\end{array}$ & $\begin{array}{l}\text { Retrospective } \\
\text { observational } \\
\text { case series }\end{array}$ & France & $\begin{array}{l}6 \\
\text { (all HIV) }\end{array}$ & $\begin{array}{l}\text { Chronic }(3-20 \\
\text { years) }\end{array}$ & $\begin{array}{l}\text { Range } 6 / 7.5- \\
6 / 15\end{array}$ & $\begin{array}{l}4 / 6 \text { showed anatomical and } \\
\text { functional improvement with } \\
\text { cessation }\end{array}$ \\
\hline $\begin{array}{l}\text { Schulze- } \\
\text { Döbold et al/ } \\
2012^{9}\end{array}$ & $\begin{array}{l}\text { Cross-sectional } \\
\text { observational } \\
\text { study }\end{array}$ & France & 10 & $\begin{array}{l}\text { Chronic (mean } \\
20 \text { years) }\end{array}$ & $6 / 9$ or better & $\begin{array}{l}10 / 18 \text { long-term poppers users } \\
\text { found to have changes }\end{array}$ \\
\hline $\begin{array}{l}\text { Davies et al/ } \\
2012^{10}\end{array}$ & Case series & UK & 7 & $\begin{array}{l}\text { Chronic } 2 \\
\text { Short term } 5\end{array}$ & $\begin{array}{l}\text { Range } 6 / 6-6 / \\
12\end{array}$ & $\begin{array}{l}\text { Dose-response suggested } \\
\text { long-term users = more severe } \\
\text { maculopathy }\end{array}$ \\
\hline $\begin{array}{l}\text { Krilis et al/ } \\
2013^{11}\end{array}$ & Case report & Australia & 1 & $\begin{array}{l}\text { Three-month } \\
\text { history, } \\
\text { fortnightly use }\end{array}$ & $\begin{array}{l}6 / 12 \text { OD, } 6 / 9 \\
\text { OS }\end{array}$ & $\begin{array}{l}\text { OCT normal, vision resolved } \\
\text { within } 24 \text { hours }\end{array}$ \\
\hline $\begin{array}{l}\text { Rabot et all } \\
2013^{12}\end{array}$ & Case report & France & 1 & & & Nil \\
\hline $\begin{array}{l}\text { Bruninx and } \\
\text { Lepiece/ } \\
2013^{13}\end{array}$ & Case report & Belgium & 1 & Single use & $6 / 9$ OU & $\begin{array}{l}\text { Spontaneous resolution 6/6 } \\
\text { after } 4 \text { weeks }\end{array}$ \\
\hline $\begin{array}{l}\text { Savary et all } \\
2013^{14}\end{array}$ & Case series & France & 2 & $\begin{array}{l}\text { Chronic } 1 \\
\text { Single use } 1\end{array}$ & $\begin{array}{l}\text { 1. OU } 6 / 6 \\
\text { 2. OU } 6 / 15\end{array}$ & $\begin{array}{l}\text { ERG_-mildly diminished } \\
\text { central response }\end{array}$ \\
\hline $\begin{array}{l}\text { Asensio- } \\
\text { Sanchez } \\
\text { et al/2014 }\end{array}$ & Case report & Spain & 1 & & & Nil \\
\hline $\begin{array}{l}\text { Gruener } \\
\text { et al/2014 }\end{array}$ & Case report & UK & 1 & Not stated & $\begin{array}{l}6 / 12 \text { OD, } 6 / 18 \\
\text { OS }\end{array}$ & $\begin{array}{l}\text { No improvement on cessation } \\
\text { at } 6 \text { months }\end{array}$ \\
\hline $\begin{array}{l}\text { Clemens } \\
\text { et al/2015 }\end{array}$ & Case series & Germany & 2 & $\begin{array}{l}\text { Sporadic } 1 \\
\text { Chronic (1 } \\
\text { year) } 1\end{array}$ & $\begin{array}{l}\text { 1. } 6 / 9,6 / 15 \\
\text { 2. } 6 / 12,6 / 15\end{array}$ & $\begin{array}{l}\text { Both pathological full field } \\
\text { ERG }\end{array}$ \\
\hline $\begin{array}{l}\text { Pahlitzsch } \\
\text { et al/2013 }\end{array}$ & $\begin{array}{l}\text { Retrospective } \\
\text { observational } \\
\text { case series }\end{array}$ & Germany & $\begin{array}{l}7 \\
(5 \mathrm{HIV})\end{array}$ & $\begin{array}{l}1 \text { Single use } 1 \\
\text { Chronic }(2-25 \\
\text { years) } 6\end{array}$ & Median 6/9 & $\begin{array}{l}1=\text { normal multifocal ERG } \\
\text { Median } 6 / 6 \text { at final visit }\end{array}$ \\
\hline $\begin{array}{l}\text { Bral et al/ } \\
2016^{19}\end{array}$ & $\begin{array}{l}\text { Retrospective } \\
\text { observational } \\
\text { case series }\end{array}$ & Belgium & $\begin{array}{l}10 \\
(7 \mathrm{HIV})\end{array}$ & Not stated & Not described & $60 \%$ used sildenafil \\
\hline $\begin{array}{l}\text { Luis et al/ } \\
2016^{20}\end{array}$ & Case report & UK & 1 & Single use & $\begin{array}{l}6 / 15 \text { OD, } 6 / 12 \\
\text { OS }\end{array}$ & $\begin{array}{l}\text { Partial resolution at } 3 \text { months, } \\
6 / 9.5\end{array}$ \\
\hline $\begin{array}{l}\text { Garcia-Bella } \\
\text { et al/2016 }\end{array}$ & Case report & Spain & 1 & Habitual & $6 / 9 \mathrm{OU}$ & Nil \\
\hline
\end{tabular}

ERG, electroretinogram; OCT, optical coherence tomography; OD, right eye; OS, left eye; OU, both eyes.

blurred vision, metamorphopsia, photopsia and fluctuating vision. The range of visual impairment described is mild to moderate, with Snellen acuity levels typically ranging from $6 / 9$ to $6 / 12$. The most useful diagnostic tool is spectral domain optical coherence tomography (OCT) which demonstrated disruption of the subfoveal outer retinal layers in all cases described with the exception of Krilis et al. ${ }^{11}$ Ophthalmoscopy can show a yellow lesion at the fovea, although this may be very subtle. Causality, while difficult to prove with $100 \%$ certainty, is anecdotally agreed among ophthalmologists, and has been interrogated in previous publications. ${ }^{10}$ Both short-term (including one-off) and long-term poppers users seem to be at risk of developing maculopathy. Published cases suggest a degree of dose-response, with more chronic users appearing at greater risk of more profound and long-lasting vision loss. It is not yet known whether the retinal 
damage is permanent, although several cases have had long-term reduction in vision in spite of cessation of use. $^{1016}$

There are currently no data regarding the prevalence of poppers maculopathy among poppers users. The purpose of this study was to estimate the prevalence of visual symptoms in users of poppers from a global perspective. This was achieved using data from the UK, Australia, the USA and the Eurozone which includes 19 countries from Europe who have adopted the Euro as their currency (Austria, Belgium, Cyprus, Estonia, Finland, France, Germany, Greece, Ireland, Italy, Latvia, Lithuania, Luxembourg, Malta, Netherlands, Portugal, Slovakia, Slovenia and Spain).

\section{METHODS}

The Global Drug Survey (GDS) conducts annual anonymous online surveys of drug and alcohol use in partnership with global media partners (in 2012 these were The Guardian and Mixmag in the UK and Fairfax Media in Australia), with onward promotion through media partner websites and social networking sites such as Facebook, Reddit and Twitter. The survey accesses a large sentinel substance using population and captures the history of drug use. It enables rapid assessment and identification of novel drugs of abuse, changing trends in substance abuse and estimations of associated symptoms. The survey was open from 11 November 2012 to 2 January 2013.

The GDS obtains generic demographic information on all respondents, including age, gender, region and country of residence. Respondents are asked specifically whether they have ever used various specific licit and illicit substances of abuse. Each time a respondent positively answers to a stem question regarding a specific substance, this leads to further questions about use of this substance. These questions are tailored each year to explore and document emerging habits, trends and risks associated with different drugs. For the purpose of this analysis, only respondents from the following areas have been included: Australia, USA, the UK and Eurozone.

In 2012, the GDS incorporated questions specific to the use of poppers and visual symptoms. The questions specifically targeted symptoms that had been described by patients with poppers maculopathy (including blurred vision, central visual disturbance, distortion, flashing lights). Negative control questions were also used: tunnel vision and unilateral symptoms. Tunnel vision was used as all cases of poppers maculopathy have solely involved the central macula and fovea, with no features of peripheral retinopathy or optic neuropathy. Likewise, all cases so far described have had bilateral (although not always symmetrical) symptoms and signs. Questions were also asked about duration of symptoms, whether or not they had improved and whether they had sought the opinion of a healthcare professional.
Ethics approval was granted by South London and Maudsley Foundation Trust Research Ethics Committee. All data preparation and analysis were undertaken using Stata V.14 (StataCorp; College Station, Texas, USA).

\section{RESULTS}

During the 2-month collection period, a total of 22289 responses were made worldwide. After removing duplicate entries, those reporting no history of drug use and those reporting use of a non-existent drug (eg, Xenorap), a total of 17479 valid responses were received from 22 countries. This included responses from the UK (6433, 36.8\%), Australia (6646, 38.0\%), the USA $(2939,16.8 \%)$ and the Eurozone $(1461,8.4 \%)$. The mean age of GDS respondents from these four regions was 31.0 years $(\mathrm{SD}=12.1$, median $=27.0, \mathrm{IQR}$ : 21-38 years). Of the $16462(94.2 \%)$ participants who provided a response for sex, $68.3 \%$ were male and $31.7 \%$ were female. The majority of participants were Caucasian (90.1\% of the 17162 provided responses). Of the $17185(98.3 \%)$ participants who provided a response to sexual orientation, $81.2 \%$ were heterosexual, $9.2 \%$ were bisexual, $7.6 \%$ were homosexual and $2.0 \%$ selected 'prefer not to answer'.

A total of $5152(29.5 \%)$ respondents had used poppers during their lifetime, of whom $1322(25.7 \%)$ had done so within the previous year and $623(47.1 \%)$ within the past month. The proportion using poppers within the past year was greater in the USA (32.8\%) than in the UK (25.9\%), Australia (24.7\%) or the Eurozone $(24.6 \%)$, though these percentages did not differ significantly $\left(\chi_{(3)}^{2}=7.56, \mathrm{p}=0.056\right)$. All further analyses refer to the 1322 respondents who reported using poppers within the past year.

Of the 623 respondents who reported using them within the past month, $258(41.4 \%)$ had only used them once, $200(32.1 \%)$ had used them 2-4 times within the previous month, 75 (12.0\%) between 5 and 9 times, $63(10.1 \%)$ between 10 and 19 times and $27(4.3 \%)$ reported using poppers more than 20 times.

When asked the question 'Do you think poppers use has affected your eyesight?', 29 people (2.2\%) responded 'yes', $130(10.0 \%)$ responded 'maybe' and $1146(87.8 \%)$ responded 'no'. When these responses were analysed by age (using multinomial logistic regression with 'no' as the reference category and age fitted as a continuous variable (likelihood ratio $\left(\chi^{2}\right)$ $=19.0, \mathrm{p}<0.001)$, the predicted probability that a respondent believed that poppers did not affect eyesight was lower among older participants. The predicted probability that poppers did not affect eyesight for a respondent aged 18 years was $91.7 \%$ : this decreased to $84.8 \%$ for a respondent aged 40 years and to $74.9 \%$ for a respondent aged 60 years. As age increased, respondents were more likely to report 'maybe' instead of 'yes' that the use of poppers affected eyesight. The 
predicted probability for an 18-year-old respondent saying yes was $1.3 \%$, this increased to $2.9 \%$ for a 40 year-old respondent and $5.7 \%$ for a 60-year-old respondent. The predicted probability for an 18-yearold respondent saying maybe was $6.9 \%$ increasing to $12.2 \%$ for a 40 -year-old respondent and $19.5 \%$ for a 60 -year-old respondent. In a multinomial logistic regression (treating an answer of 'maybe' as a response lying between 'no' and 'yes'), fitting age as a linear continuous variable was significant and with the reference category of 'no', the OR for age with a respondent reporting 'maybe' was 1.03 (95\% CI 1.01 to 1.05). The OR for age with respondent reporting 'yes' was 1.04 (95\% CI 1.01 to 1.07 ).

When asked about the progression or improvement of vision problems in relation to cessation or continuation of poppers use, 16 participants $(15.4 \%$ of the 104 participants who provided responses) reported that when they stopped using poppers, their symptoms either remained the same or deteriorated. Thirty-seven participants $(35.6 \%)$ reported that their symptoms had improved after cessation. Of those participants who reported continued use of poppers, 34 (32.7\%) reported continuation of symptoms and 17 (16.3\%) reported that their symptoms had improved. Of the 51 participants who continued using poppers in the previous year, exactly one-third $(17,33.3 \%)$ reported that their visual symptoms improved in spite of this and $34(66.6 \%)$ reported that they continued to experience visual symptoms. Of the 53 participants who ceased using poppers during the past year, 27 (51\%) reported that their symptoms disappeared, 4 (7\%) stated that their symptoms got worse and the remaining 22 (42\%) reported that their symptoms remained despite ceasing their use of poppers.

Table 2 provides further details regarding answers to specific symptom-related questions. Of the 1322 people who reported using poppers in the past 12 months, 159 (12.0\%) people believed that the use of poppers either may have or definitely affected their

Table 2 Visual symptoms reported by 1322 past-year poppers users

\section{Since you first used poppers, do you think they have affected your eyesight?}

Total ( $\mathrm{N}=1322), \mathrm{n}(\%)$

\section{No}

Maybe

Yes

Missing data
$1146(86.7)$

$130(9.8)$

29 (2.2)

17 (1.3)

\section{Have you noticed any of the following in the hours or days following poppers use?}

\begin{tabular}{|c|c|c|c|c|}
\hline & $\mathbf{n}$ & $\%$ (Based on $\mathrm{N}=1$ 322) & $\begin{array}{l}\% \text { (Based on } \\
\mathrm{N}=159)\end{array}$ & \\
\hline Blurred vision & 39 & 3.0 & 24.5 & \\
\hline Patch in the centre of vision & 23 & 1.7 & 14.5 & \\
\hline Fluctuating vision & 28 & 2.1 & 17.6 & \\
\hline Flashing lights & 20 & 1.5 & 12.6 & \\
\hline Distorted vision & 10 & 0.8 & 6.3 & \\
\hline Tunnel vision* & 5 & 0.4 & 3.1 & \\
\hline Other & 23 & 1.7 & 14.5 & \\
\hline \multicolumn{5}{|c|}{ 3. What has happened to your vision problems over the last year? $(\mathrm{N}=104), \mathrm{n}(\%)$} \\
\hline \multicolumn{4}{|c|}{ I stopped using poppers and my vision problems went away completely } & $27(26.0)$ \\
\hline \multicolumn{4}{|c|}{ I stopped using poppers and my vision problems got a bit better } & $10(9.6)$ \\
\hline \multicolumn{4}{|c|}{ I stopped using poppers but my vision problems have stayed the same } & $12(11.5)$ \\
\hline \multicolumn{4}{|c|}{ I stopped using poppers but my vision problems have got worse } & $4(3.9)$ \\
\hline \multicolumn{4}{|c|}{ I carried on using poppers but my vision problems have got better anyway } & $17(16.4)$ \\
\hline \multicolumn{4}{|c|}{ I carried on using poppers and I am still having some problems } & $34(32.7)$ \\
\hline
\end{tabular}


eyesight. Of these, with regard to the two quality control questions, only five (3.1\%) responded that they experienced tunnel vision. When asked whether only one eye or both eyes were affected (asymmetrically or symmetrically), 109 responses were given: 8 (7.3\%) respondents thought the changes were in one eye only, $11(10.1 \%)$ had symptoms in both eyes but asymmetrical and $90(82.5 \%)$ had bilateral symmetrical symptoms. With regard to symptoms associated with poppers use, $78(49.1 \%)$ people reported at least one of the five listed symptoms, 47 (29.6\%) people reported only one symptom, 23 (14.5\%) people reported two symptoms, $6(3.8 \% \%)$ people reported three symptoms and with one person reporting four symptoms and another person reporting five symptoms. Of the symptoms, 39 (24.5\%) people indicated experiencing blurred vision and $28(17.6 \%)$ people indicated experiencing fluctuating vision in the hours and days after using poppers. Of the 159 participants who reported definite or possible symptoms associated with the use of poppers, $23(14.5 \%)$ used free text to describe their visual symptoms. In summary of these responses, two respondents specifically commented that visual symptoms were associated with the replacement of isobutyl nitrite with isopropyl nitrite (see Discussion section), three described central visual disturbance, six reported altered colour perception, six described non-specific symptoms of blurred vision or visual disturbance and seven respondents provided irrelevant symptom description such as presbyopia and dry eyes. From this same cohort of 159 respondents, only $19(11.9 \%)$ reported visiting a health professional (either an optometrist or specialist eye doctor) regarding their symptoms and only three of those mentioned the use of poppers.

\section{DISCUSSION}

This is the only study to date that assesses the prevalence of visual symptoms in poppers users. The findings demonstrate that a small, yet significant from a public health perspective, number of users report visual disturbance which they associate with the use of poppers. When asked which of a range of specific symptoms they had experienced, the majority of participants reported symptoms similar to those described by patients with confirmed poppers maculopathy (including blurred vision, a patch in the centre of their vision and fluctuating vision). Likewise few respondents thought that they had tunnel vision or symptoms affecting only one eye. Both of these were effective control questions as all previous reports have described both central visual disturbance and bilateral symptoms, although sometimes asymmetrical. ${ }^{7-21}$ Respondents were given the option of providing free text to describe their symptoms, and this produced some interesting responses. Qualitative analysis of these free-text responses suggests that about half of the described symptoms could potentially be related to maculopathy, with suggestions of central visual disturbance, alterations to colour perception, scotoma or loss of clarity. The rest of the symptoms were less straightforward to interpret or were more typical of non-maculopathy conditions (eg, dry eye, red eye, updated reading glasses required).

In this study, almost $30 \%$ of all respondents had used poppers at some stage during their lives, supporting findings of previous studies that lifetime poppers use is not uncommon ${ }^{1}{ }^{2}$ and likely attributable to response bias to the GDS previously described. ${ }^{22}$

There was a positive correlation between increasing age and presence of symptoms. This finding reflects previously described cases of clinically confirmed poppers maculopathy ${ }^{7-21}$ who had a mean age of 39 , which might be older than would be expected if poppers maculopathy was independent of age. There are several possible explanations for this. It may be that older users are more aware of symptoms, and more exacting, demanding or aware of sensory perception. They may also be more likely to seek healthcare advice, leading to the identification of the condition. It could be considered that this age related bias is removed by this study, suggesting an alternative explanation in that the physiological properties of the retina differs with increasing age and leaves an individual at greater risk of developing pathological changes.

With regard to the responses provided when questioned about the progression of symptoms, there was a mixture of some patients stopping using poppers while others continued, and some patients having improvement of symptoms while others had ongoing symptoms. This bears some similarity to the clinical findings in the UK case series. ${ }^{10}$ This gives four potential groups of people each of which was represented in the UK case series and each of which is represented in the findings of the present study.

Poppers have been used for several decades, ${ }^{1}{ }^{2}$ however it is only in recent years that poppers maculopathy has been accurately described. ${ }^{7-21}$ One reason for this may be the advent of OCT technology that has enabled accurate/definitive diagnosis of this condition. However, from a UK perspective at least, the recognition of poppers maculopathy coincided with a switch of the most commonly used compound from isobutyl nitrite to isopropyl nitrite. This switch occurred after legislation changes rendered isobutyl nitrite illegal to supply. ${ }^{23} 24$ Two respondents in the present study stated specifically that their visual problems only began after switching to the more volatile isopropyl nitrite. Unfortunately, there are little data confirming global trends in specific substances that are used in poppers, making any further assumptions difficult.

It is interesting that so few respondents who thought that poppers may have affected their vision sought professional advice, with only three respondents revealing their use of poppers to either an optometrist or specialist eye doctor. In the UK, there was a modest amount of media interest following the 
publication of the UK case series. ${ }^{25}$ It is not known whether this has increased awareness of ophthalmic risks among poppers users. There are numerous webpages providing advice to recreational drug users, and it is quite common to read that poppers can affect eyesight, but with little more information typically available. Increased publicity of this condition may encourage people to seek appropriate healthcare advice, particularly of the specific nature of the dangers involved, including the possibility of young people being left with visual acuity below the legal driving standard.

One limitation of this study, and of any study related to poppers, is that it is difficult to measure exposure and therefore difficult to measure dose-response. We have used a surrogate of how many days per month poppers were used, but this still does not quantify the volume of vapour that was inhaled.

This study provides a starting point for further clinical analysis. It is of course not possible to state that respondents with visual symptoms definitively had poppers maculopathy and there is a definite need for clinical analysis to confirm how frequent poppers maculopathy is in the real world and, subsequently, the extent to which it poses a genuine public health risk. The results from this study suggest that poppers maculopathy is prevalent among non-treatment-seeking poppers users.

Contributors ARW conceived the study and collected the data. AJD led all authors in drafting the manuscript. JF conducted the analyses. All authors edited and approved the final manuscript.

Funding Global Drug Survey Ltd is an independent self-funded organization. The authors received no financial support for the research, authorship, and/or publication of this article.

Competing interests ARW is the owner and founder of Global Drug Survey (GDS) and has previously provided expert opinion on the use, risk and potential for health harms to the legal team that represented Perpol (the biggest supplier of Isopropyl nitrite In Europe).

Provenance and peer review Not commissioned; externally peer reviewed.

Open Access This is an Open Access article distributed in accordance with the Creative Commons Attribution Non Commercial (CC BY-NC 4.0) license, which permits others to distribute, remix, adapt, build upon this work noncommercially, and license their derivative works on different terms, provided the original work is properly cited and the use is non-commercial. See: http:// creativecommons.org/licenses/by-nc/4.0/

\section{REFERENCES}

1. Sigell LT, Kapp FT, Fusaro GA, et al. Popping and snorting volatile nitrites: a current fad for getting high. Am J Psychiatry 1978;135: $1216-8$.

2. Lockwood GB. Poppers: volatile nitrite inhalants. Pharm J 1996;257: 154-5.

3. Smith K, Flatley J. Drug Misuse Declared: Findings from the 2010/11 British Crime Survey. London: UK Home Office, 2011.

4. Ashworth S, Fountain J. Part of the Picture - The National LGB Drug \& Alcohol Database. Manchester: The Lesbian and Gay Foundation, 2011. http://lgbt.foundation/assets/ files/documents/may 12/ FENT_1335882447_POTP_Year2_Report_FINAL.pdf (accessed Nov 2015).

5. Winstock A. Mixmag Drugs Survey: Mixmag. London: Development Hell Ltd, 2011.

6. Nutt D, King LA, Saulsbury W, et al. Development of a rational scale to assess the harm of drugs of potential misuse. Lancet 2007;369: 1047-53.

7. Vignal-Clermont C, Audo I, Sahel JA, et al. Poppers-associated retinal toxicity. N Engl J Med 2010;363:1583-5.

8. Audo I, El Sanharawi M, Vignal-Clermont C, et al. Foveal damage in habitual poppers users. Arch Ophthalmol 2011;129:703-8.

9. Schulze-Döbold C, Ben Denoun M, Dupas B, et al. Retinal toxicity in users of "poppers". Ann Intern Med 2012;156:670-2.

10. Davies AJ, Kelly SP, Naylor SG, et al. Adverse ophthalmic reaction in poppers users: case series of 'poppers maculopathy'. Eye 2012;26: 1479-86.

11. Krilis M, Thompson J, Atik A, et al. 'Popper'-induced vision loss. Drug Alcohol Rev 2013;32:333-4.

12. Rabot A, Pinon F, Baillif S. SD-OCT appearance in acute poppersassociated macular toxicity. J Fr Ophtalmol 2013;36:388-9.

13. Bruninx R, Lepiece G. Didactic image poppers maculopathy. Bull Soc Belge Ophtalmique 2013;(322):133-5.

14. Savary P, Biotti $D$, Abouaf $L$, et al. Poppers toxic maculopathy misdiagnosed as atypical optic neuritis. Eur J Neurol 2013;20:e90-1.

15. Pahlitzsch M, Draghici S, Mehrinfar BM, et al. Poppers-associated maculopathy. Klin Monbl Augenheilkd 2013;230:727-32.

16. Asensio-Sánchez VM, Gonzalez-Buendia L, Marcos-Fernández M. Maculopathy due to drug inhalation. Arch Soc Esp Oftalmol 2014;89: 313-5.

17. Gruener AM, Jeffries MA, El Housseini Z, et al. Poppers maculopathy. Lancet 2014;384:1606.

18. Clemens CR, Alten F, Loos D, et al. Poppers maculopathy or retinopathy? Eye 2015;29:148-9.

19. Bral NO, Marinkovic M, Leroy BP, et al. Do not turn a blind eye to alkyl nitrite (poppers)! Acta Ophthalmol 2016;94:e82-3.

20. Luis J, Virdi M, Nabili S. Poppers retinopathy. BMJ Case Rep 2016; 2016:bcr2016214442.

21. García-Bella J, Donate J, Gallego-Pinazo R, et al. "Poppers maculopathy?" in Spain. A new ophthalmological disease. Arch Soc Esp Oftalmol 2016;91:397-9.

22. Winstock AR, Borschmann R, Bell J. The non-medical use of tramadol in the UK: findings from a large community sample. Int $J$ Clin Pract 2014:68:1147-51.

23. The Stationary Office. The Dangerous Substances and Preparations (Safety) Regulations 2006. London: The Stationary Office, 2006.

24. Davies S, Salina J, Ramsey J, et al. Analysis of the Volatile Alkyl Nitrites. http://www.the-ltg.org/data/uploads/posters/alkyl-nitrites_ final.pdf (accessed Nov 2015).

25. BBC News Mancester. Royal Bolton Hospital study links use of "poppers" with eyesight damage. 2012. http://www.bbc.co.uk/news/ uk-england-manchester-20039569 (accessed Nov 2015). 